\title{
33. TRANSFORMATION OF OPALINE SILICA IN SEDIMENTS FROM BAY OF BISCAY AND ROCKALL BANK
}

\author{
Hideo Kagami, Ocean Research Institute, University of Tokyo
}

\begin{abstract}
$\mathrm{X}$-ray powder diffraction analyses of sponge spicules and radiolarians taken from cores drilled at the Bay of Biscay and Rockall Bank in the northeast Atlantic show marked changes in silica minerals. In Hole 400A, opal-A exists in the Miocene-Oligocene sequence, opal-A coexists with clinoptilolite which shows pseudomorph from biogenous shells in the Eocene-Paleocene sequence, and opal-CT coexists with the clinoptilolite in the Albian sequence. Formation of the clinoptilolite may be controlled by concentration of aluminum and alkali ions which is supported by silicate reactions observed in the interstitial water of the site.

The mode of occurrence indicates that opal-CT alone occurs when calcium carbonate in sediments is over 80 per cent. The marked depletion of alkalinity in Site 406 and the scarcity of aluminum and metallic cations in interstitial solutions seems to favor precipitation of opal-CT.

The origin of the bedded cherts in the Miocene-Oligocene and Eocene sequences at Hole $400 \mathrm{~A}$ may be explained by the sedimentary processes such as turbidity currents and winnowing currents, for example, contour currents. A nodular type porcelanite at Site 406 may be formed by the deposition of silica as colloidal state which have been dissolved from the nearby diatomite layer.
\end{abstract}

\section{INTRODUCTION}

Silica accumulates in observable quantities in marine sediments as planktonic and benthic debris in the stratigraphic sequence of high primary production. Diagenetic transformation of the natural hydrous silica leads to classifications as follows; (1) amorphous silica (opal-A), (2) disordered $\alpha$-cristobalite (opal-CT), and (3) quartz (Jones and Segnit, 1971). The whole reaction may be formed by a dissolution-redeposition mechanism, although a solid-solid inversion was claimed for the latter reaction (Ernst and Calvert, 1969). Stein and Kirkpatrick (1976) have suggested a model involving nucleation and growth of quartz by a dissolution-reprecipitation mechanism.

The source of the silica in the deep-sea cherts is considered to be biogenous opal and volcanic debris (Calvert, 1971). Heath and Moberly (1971) observed that the cherts contain very little biogenous opal, though the surrounding sediments contain corroded siliceous tests. They inferred that the silica has come from the biogenous opal migrating within the sediments over distances of the order of a few centimeters to meters. The solution of silica from biogenous shells or glass shards depends on their size. Preliminary examination of the dinoflagellate revealed rich assemblages from sediments of middle Miocene to Recent in the Bay of Biscay sites. The majority of the dinoflagellate cysts have been dissolved out of cores older than middle
Miocene although other larger siliceous organisms are rich and diverse.

The deep-sea silica minerals which are mainly opal-CT range from Pliocene to Late Cretaceous in age, while those of quartz are generally, but not invariably older (Calvert, 1974). As for the process and factors responsible for the formation of chert, two opposing theories have been considered: (1) one is the diagenetic theory stating that the transformation from opal-CT to quartz is mainly due to a time-dependent (aging) process (Heath and Moberly, 1971; von Rad and Rösch, 1974), and (2) the other is the quartz precipitation theory suggesting the compositions of the host sediments control the formation of cherts (Lancelot, 1973). Lancelot described a relationship between the mineralogy of the cherts and composition of the host sediments, observed that porcelanites in clayey sediments were composed of disordered $\alpha$-cristobalite, while cherts occurring in carbonates consisted predominantly of quartz, and concluded that quartz precipitated directly in the carbonate matrix. Kanster et al. (1977) noted that quartz could crystallize from solution only when the silica concentration is below the inferred equilibrium solubility of opal-CT, and that in most deep-sea sediments with high concentrations of siliceous skeletal remains, the diagenetic sequence opal-A $\rightarrow$ opal-CT $\rightarrow$ quartz would predominate.

The objective of this paper is to contribute to clarification of the transformation of opaline silica by a coarse fraction 
study and diagenetic interpretation of the siliceous organisms.

\section{SEDIMENTARY PROCESSES OF THE SILICEOUS CHALK/PORCELANITE LAYERS AT HOLE 400A}

The siliceous chalks observed in the Miocene/Oligocene sequence are thin, gritty (silty) interlayers within nannofossil chalk. They are often 1 to $3 \mathrm{~cm}$ thick with sharp lower boundary and relatively gradational upper boundary. They are light bluish gray to pinkish gray in color and are generally coarser toward the bottom. Parallel, lenticular, and cross laminae are rarely observed. The gritty layers consist of approximately 25 to 40 per cent sponge spicules and radiolarians on the basis of smear-slide observation. The other constituents are 15 to 30 per cent detrital minerals and 35 to 60 per cent $\mathrm{CaCO}_{3}$. The layers observed in the Miocene-Oligocene sequence such as Cores 43 and 44 show very sharp lower boundary and upward grading from coarse to finer particles with laminations. The sharp boundary is suggestive of slight channeling of the underlying sediments. Sometimes the layers are convoluted into recumbent folds as a result of local slumping. As far as composition of the fraction coarser than $44 \mu \mathrm{m}$ is concerned, the gritty layers in the Miocene/Oligocene sequence are relatively rich in detrital quartz and calcareous benthic foraminifers (Figure 1). Siliceous organisms are dominantly sponge spicules.

On the other hand, porcelanite layers in the Eocene sequence are composed of clean silt grains having parallel and cross laminations without obvious grading. Compositions of the coarse fraction in the Eocene sequence are poor in foraminifers, detrital quartz, and feldspar, but concentration of siliceous organisms especially of radiolarians is observed (Figure 1). They are apparently associated almost entirely with pelagic sedimentation, and winnowed by a current action during or after the deposition. Various depositional structures have been observed in the chert layers and the depositional processes to concentrate siliceous organisms have been proposed (McBride and Thompson, 1970; Imoto and Fukutomi, 1975).

To estimate frequency of the siliceous beds, the number of the siliceous chalks and porcelanite layers within a known length of the cores has been counted (Table 1). Two dominant positions of the siliceous enrichment through the sequences are observed; one is present around Cores 43 and 44 where remarkable slumping occurs. The appearance ratio is 2 to 4 layers per meter for the cores. The other is present around Cores 51 and 52 with the appearance ratio of 2 layers per meter. Some of the layers in this group are visibly recrystallized to be porcelanite. The appearance ratio is plotted on the fourth column in Figure 1. These siliceous enrichment groups differ in mode of occurrence, sedimentary structures, and compositions mentioned already, which suggests that they are formed by different sedimentary processes. The evidence indicates that the Miocene/Oligocene siliceous layers may have been formed by a turbidity current, and the Eocene porcelanite by a contour current.

\section{MINERAL ASSEMBLAGES IN THE BULK, COARSE FRACTIONS, AND SEPARATED SAMPLES}

Form, texture, and optical properties of the coarse fractions were studied under the microscope, and some of the results are illustrated in Figures 1 and 2. The use of an $\mathrm{X}$-ray diffractometer was effective for detailed investigation of microcrystalline or cryptocrystalline minerals such as zeolite and opaline silica.

Bulk samples of siliceous chalk and porcelanite from which the coarse fractions were washed in a sieve coarser than $44 \mu \mathrm{m}$, and siliceous organisms separated by hand-picking with the aid of a binocular were used for taking X-ray powder patterns. Heat treatment in the oven has been performed for identification of zeolite.

The bulk analysis of the siliceous chalk/porcelanite in Hole 400A is shown in Table 2. A difference in authigenic minerals occurs between the Oligocene and Eocene sequences. Siliceous chalks in the Oligocene are composed of opal-A, while porcelanites in the Eocene are of clinoptilolite and opal-CT. Quartz is observed as a major constituent. Because the quartz comprises the major part of the coarse fraction $(>44 \mu \mathrm{m})$ as shown in Figure 1 and Table 3 , it is considered the detrital mineral.

The bulk analysis of chalk/diatomite from Site 406 indicates the same transformation from opal- $\mathrm{A}$ in the middle to early Miocene to opal-CT without clinoptilolite in the late Eocene (Table 2). Diatomites in Samples 38,CC and 39, CC are composed of opal-A and the surface appearance is nearly fresh as indicated in column 6 of Figure 2, while opal-CT occurs in Samples 37,CC and 40, CC at the peripheral part of this concentrated diatomite. This is a nodular-type porcelanite. Quartz is identified in association with opal-CT. It is found in the coarse fraction analysis (Figure 2) and is considered to be detrital in part. Samples $37, \mathrm{CC}$ and $40, \mathrm{CC}$ contain over 80 per cent $\mathrm{CaCO}_{3}$. From the stratigraphic sequence, opal-CT may have been derived from the dissolution of the diatomite.

The coarse fractions sieved at $44 \mu \mathrm{m}$ were examined (Table 3). The calcium carbonate content of the bulk sample taken from Hole $400 \mathrm{~A}$ is less than 70 per cent. The mineral assemblage of the low-carbonate sediments is characterized by the successive transformation of silica from opal-A in the Miocene/Oligocene sequence, through clinoptilolite plus opal-A in the Eocene-Paleocene, to clinoptilolite plus opal-CT in the Albian. The absence of opal-CT in the Eocene differs from the bulk analysis listed in Table 2. This is probably due to the size of opal-CT formed. Scanning electron microscopy reveals the deep-sea porcelanites are composed of silica spheres of 10-15 $\mu \mathrm{m}$ diameter (Weaver and Wise, 1972). It is also evident from Table 3 that the coarse fractions have the same transformation trend with the dilatory reaction time as that of bulk samples. The difference in reaction time between bulk and coarse fraction samples may be due to size of the siliceous organic fractions, if the other condition does not change.

To understand transformation of clinoptilolite, siliceous organisms of sizes larger than $44 \mu \mathrm{m}$ were picked up with the aid of the binocular and examined by X-ray diffractometer (Table 4). They are composed mainly of sponge spicules in the Miocene/Oligocene and Eocene sequences, and of radiolarians for the Eocene and Albian. Sponge spicules in the Miocene/Oligocene are identified to be opal-A, and those in the Eocene are opal-A plus clinoptilolite. Amount and/or crystallinity of the clinoptilolite increase downward. Radiolarians identified in the Eocene are clinop- 


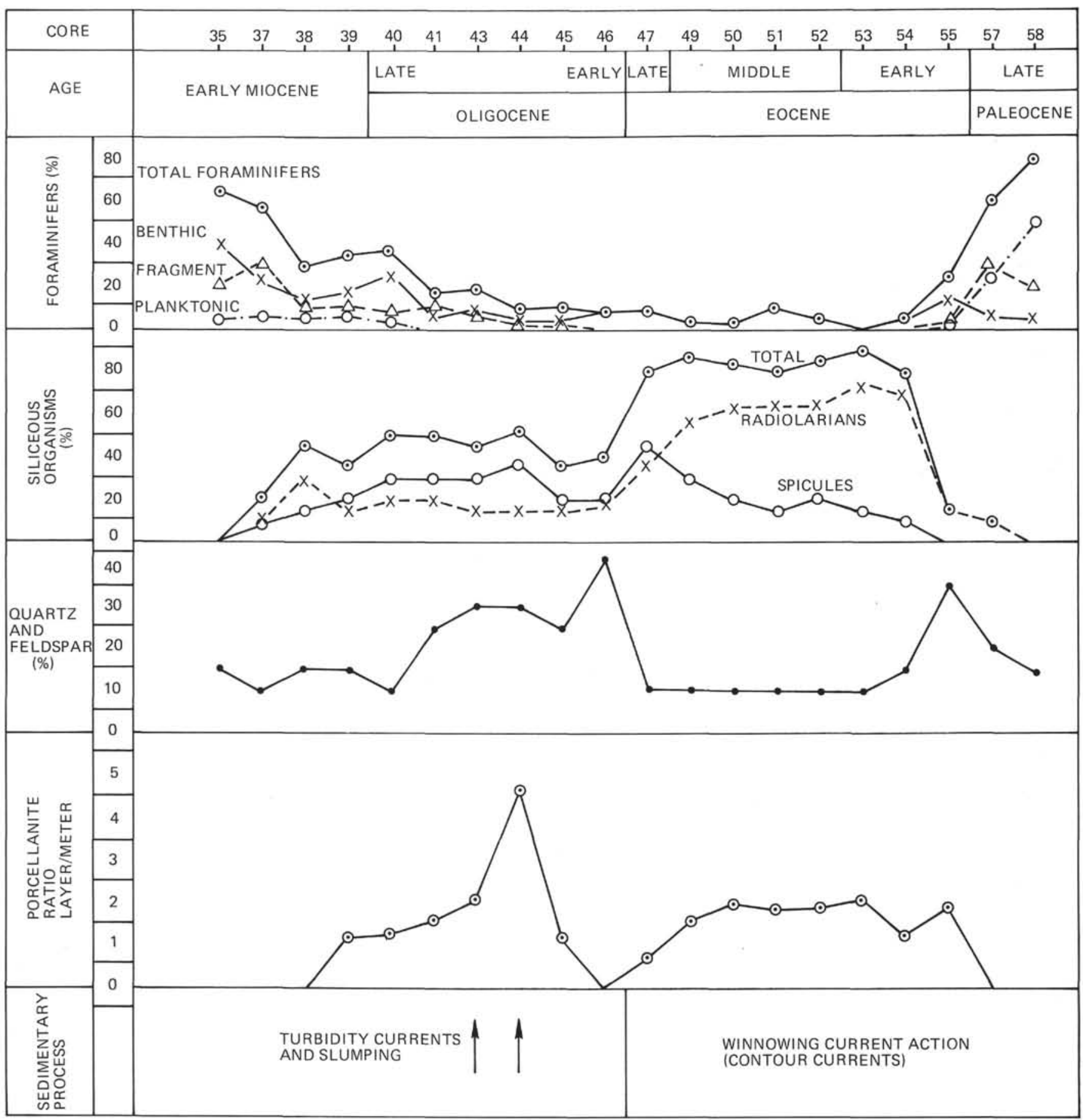

Figure 1. Coarse fraction analysis $(>44 \mu \mathrm{m})$, porcelanite ratio including siliceous chalks, and sedimentary processes to concentrate siliceous biogeneous shells.

tilolite only. From their peak intensity, crystallinity increases downward. The zeolitized radiolarian spherules are often reported (von Rad and Rösch, 1974). Compared with sponge spicules in the same core, radiolarians are apt to be easily transformed into clinoptilolite. This is because sponge spicules have thicker and more homogeneous tube walls which persist to dissolve for a longer time (Inoue, 1973), and because radiolarians have finer and more fragile structures. Radiolarians taken from the Albian are com- posed of opal-CT plus clinoptilolite. The coarse fractions from Samples 65,CC and 66,CC are composed entirely of clinoptilolite with a good crystallinity, which is indicated by their stability after heating 8 hours at $450^{\circ} \mathrm{C}$. They seem to be tabular or platy crystals under the binocular, and might have been fractured from pseudomorphs of the original radiolarian spherules. From the occurrence and siliceous species mentioned above, clinoptolite seems to precipitate prior to formation of opal-CT in this environment. 
TABLE 1

Siliceous Chalk/Porcelanite Appearance Ratio in Hole 400A

\begin{tabular}{lcccl}
\hline Core & $\begin{array}{c}\text { Core } \\
\text { Thickness } \\
(\mathrm{cm})\end{array}$ & $\begin{array}{c}\text { Number of } \\
\text { Porcelanite } \\
\text { Layer }\end{array}$ & $\begin{array}{c}\text { Ratio } \\
\text { (Layer/m) }\end{array}$ & Remarks \\
\hline 37 & 584 & 0 & 0 & \\
38 & 191 & 0 & 0 & \\
39 & 260 & 3 & 1.2 & \\
40 & 303 & 4 & 1.3 & \\
41 & 61 & 1 & 1.6 & \\
42 & 16 & 0 & 0 & Slumping \\
43 & 745 & 16 & 2.1 & \\
44 & 173 & 8 & 4.6 & Slumping \\
45 & 714 & 9 & 1.3 & \\
46 & 415 & 0 & 0 & \\
47 & 150 & 1 & 0.7 & \\
48 & 315 & 0 & 0 & \\
49 & 568 & 9 & 1.6 & \\
50 & 50 & 1 & 2.0 & \\
51 & 975 & 19 & 1.9 & Recrystallized \\
52 & 732 & 14 & 1.9 & Recrystallized \\
53 & 190 & 4 & 2.1 & \\
54 & 340 & 4 & 1.2 & \\
55 & 269 & 5 & 1.9 & \\
56 & 241 & 0 & 0 & \\
57 & 201 & 0 & 0 & \\
58 & 10 & 0 & 0 & \\
59 & 104 & 0 & 0 & \\
\hline
\end{tabular}

\section{ORIGIN OF CLINOPTILOLITE AND OPAL-CT}

A very high alkalinity which could be observed in the saline lakes is detected in the Bay of Biscay site.

Interstitial water chemistry of Hole $400 \mathrm{~A}$ (see Site Report, this volume) suggests that $\mathrm{Ca}^{++}$increases gradually downwards, being minimal in the first 100 meters to concentrations greater than that of seawater. This change may correspond depletion in $\mathrm{HCO}_{3-}, \mathrm{Na}^{+}$, and $\mathrm{K}^{+}$for reasons mentioned later. Removal of $\mathrm{Na}^{+}$and $\mathrm{K}^{+}$is generally accompanied by loss of alkalinity, indicating these catons are probably lost through silicate reactions of the reverse weathering type proposed by MacKenzie and Garrels (1966). Formation of Na-montmorillonite, illite, and their mixed-layer minerals would be the most suitable silicate reactions.

Consumption of $\mathrm{Na}^{+}$and $\mathrm{K}^{+}$also occurs in the formation of clinoptilolite. Here, dissolution of amorphous silica of the siliceous organisms may demonstrate the following empirical relationship.

Aluminum hydroxyl complex and alkaline ions are common in the seawater which may be supplied in the interstitial water. They are also supplied by clay dissolution. As noted already, clinoptilolite might be formed directly from glass or a gel without a clay precursor when the extremely high concentration of these ions (Surdam and Parker, 1972). It is also noted that no clay minerals are amorphous silica aluminum hydroxyl complex

$$
\begin{aligned}
& 7 \mathrm{Si}(\mathrm{OH})_{4}+2 \mathrm{Al}\left(\mathrm{H}_{2} \mathrm{O}\right)_{\mathrm{k}}(\mathrm{OH})_{\mathrm{m}} \\
& +\left(2 \mathrm{Na}^{+}, 2 \mathrm{~K}^{+}, \mathrm{Ca}^{2+}\right)+4 \mathrm{HCO}_{3}{ }^{-} \leftrightharpoons \\
& \left(\mathrm{na}_{2}, \mathrm{~K}_{2} \mathrm{Ca}\right)\left[\mathrm{Al}_{2} \mathrm{Si}_{7} \mathrm{O}_{18}\right] 6 \mathrm{H}_{2} \mathrm{O}+\mathrm{nH}_{2} \mathrm{O}+4 \mathrm{CO}_{2} \\
& \text { clinoptilolite }
\end{aligned}
$$

detected on X-ray patterns from coarse fractions associated with the Eocene clinoptilolite.

Interstitial water chemistry in Hole $400 \mathrm{~A}$ indicates that total alkaline earths increase downward and exceed that in the seawater below the Oligocene as shown in Figure 3. On the other hand, alkalinity measurements indicate gradual decrease downward to the level of the seawater at the depth of the Eocene. Since alkalinity balance is affected by all of the cations in the interstitial water (Manheim and Sayles, 1974), alkaline earth enrichment may be balanced by depletion of alkali cations such as $\mathrm{Na}^{+}$and $\mathrm{K}^{+}$. Marked concentration of alkaline earths in Hole 400A (Figure 3) is balanced by depletion of alkali cations especially of $\mathrm{Na}^{+}$in the interstitial water, which may suggest silicate reactions. The high alkalinity is caused by bicarbonate concentration by way of sulfate reduction process. Mariner and Surdam (1970) noted that the activity of silica was high in alkali solutions, but the activity of alumina increased more rapidly with increase in alkalinity. The $\mathrm{Si} / \mathrm{Al}$ ratio is the controlling factor for the zeolite formation and the concentration of alumina would be favored in the Hole $400 \mathrm{~A}$ environment.

The marked depletion of the alkaline earths in Site 406 especially of $\mathrm{Mg}^{++}$is obvious in Figure 3. This could be explained by formation of magnesian calcite in the sediment with high carbonate contents, although $\mathrm{Mg}$-silicate authigenesis cannot be ruled out. This marked depletion of the alkaline earths explain the low alkalinity through the core and, therefore, any reactions of the reverse weathering type may be impossible at this site. As a consequence of the marked depletion of alkalinity in Site 406, the formation of opal-CT would be favored over clinoptilolite.

In order to explain crystallization in Eocene porcelanites and the amorphous state in Miocene/Oligocene siliceous chalks in Hole 400A, it is worthwhile to consider the sedimentary processes which worked on these layers. Because the Eocene porcelanites are thought to be winnowed from the original deposition which had relatively abundant clay (50-70\%) by some process of bottom currents, for example, contour currents, they might show higher permeability values than the surrounding clayey formation. On the other hand, Miocene/Oligocene siliceous chalk layers are deposited as a basal layer by a process of turbidity currents and are, therefore, likely covered by silty layers soon after their deposition. This is remarkably different from the Eocene porcelanites which may be kept uncovered for a while by the action of winnowing currents. Since the Eocene siliceous organisms deposited as particle-by-particle sedimentation and are later winnowed, the time required to attain $1 \mathrm{~cm}$ thick might be about 1000 years at a minimum (Site Report, this volume). The sedimentation rate of the basal part of the Miocene/Oligocene turbidite would be almost a moment and covered by the upper sequence of the turbidite instantaneously in the geological time. For these reasons, natural hydration might have played a great role in the silicification of the Eocene porcelanite during the initial stages. The high permeability of the porcelanite layer could contribute to hydration during the subsequent stages. Addition of clay particles to the siliceous organisms-seawater system causes the decrease of the permeability in the system and no opal-CT crystallization is detected consequently (Kastner et al., 1977). 


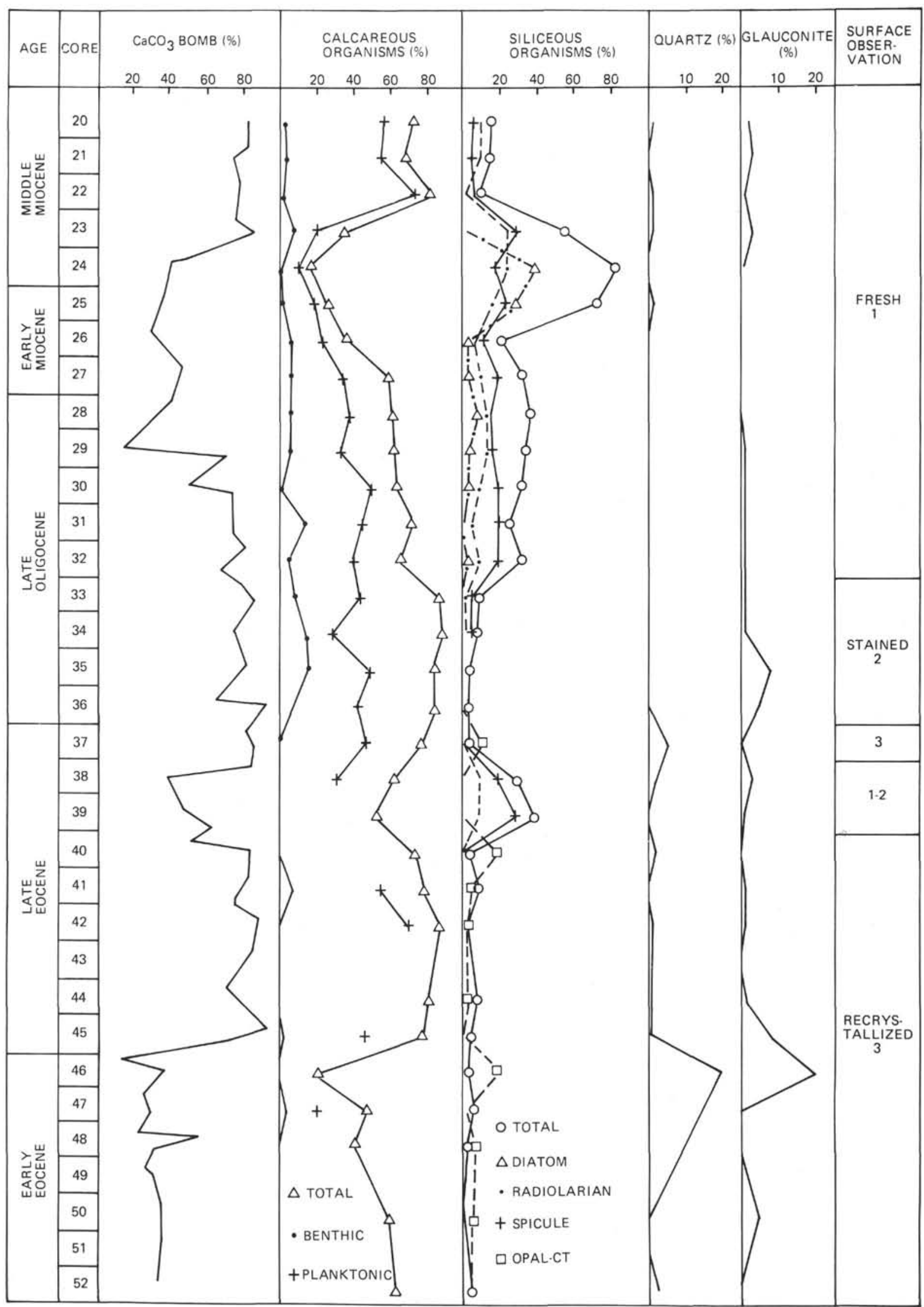

Figure 2. Coarse fraction analysis $(>44 \mu \mathrm{m})$, calcium carbonate bomb data, and observation of siliceous organism under the binocular. Samples are from core catchers at Site 406 of the Rockall Bank. 
TABLE 2

Bulk Analysis of Siliceous Chalk/Porcelanite Layers

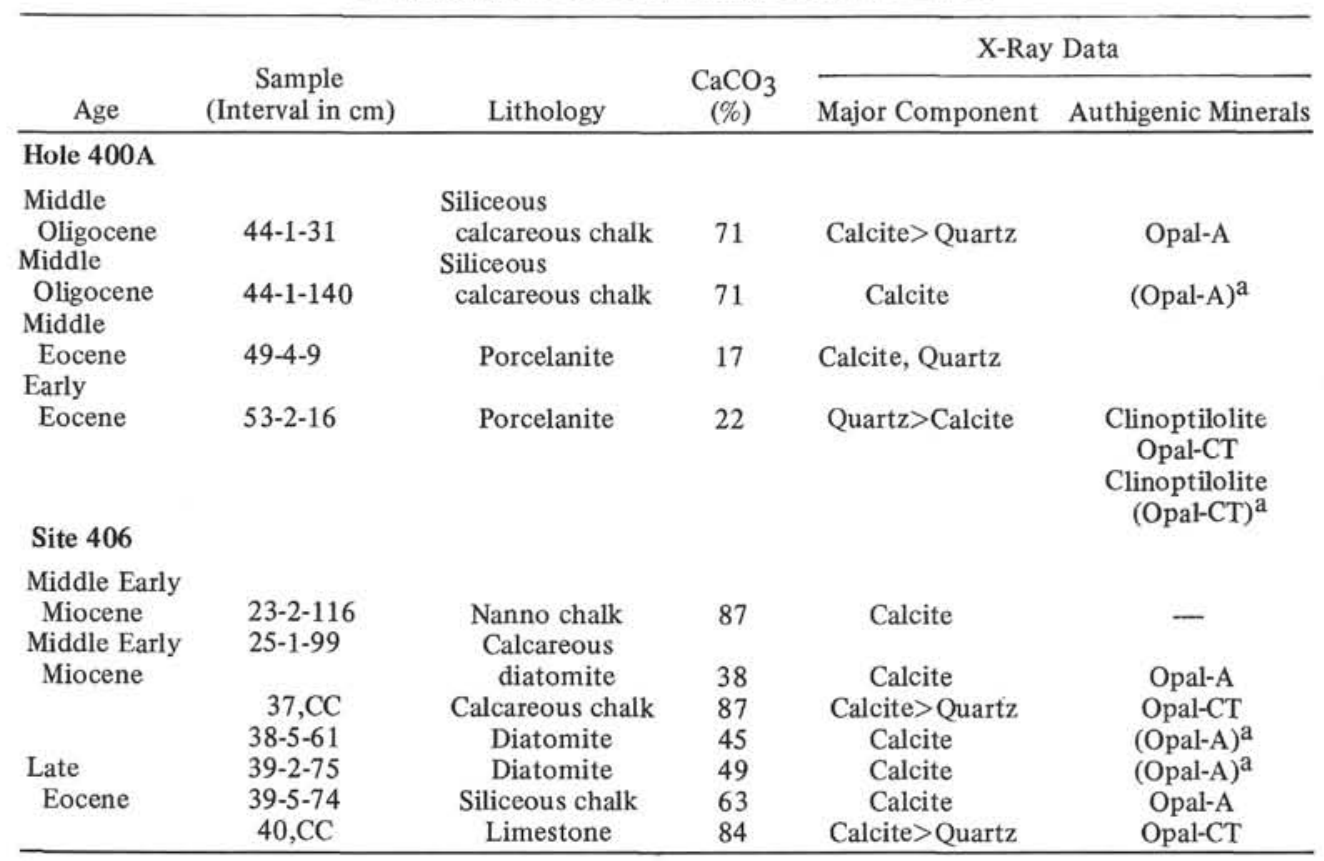

aDenotes rare occurrence.

TABLE 3

X-Ray Powder Diffraction Data of Coarse Fractions ( $>44 \mu \mathrm{m})$ in Hole 400A

\begin{tabular}{|c|c|c|c|c|c|}
\hline \multirow[b]{2}{*}{ Age } & \multirow[b]{2}{*}{ Sample } & \multirow[b]{2}{*}{ Lithology } & \multirow{2}{*}{$\begin{array}{l}\mathrm{CaCO}_{3} \\
(\%)\end{array}$} & \multicolumn{2}{|c|}{ X-Ray Data } \\
\hline & & & & Non-Authigenic & Authigenic \\
\hline $\begin{array}{l}\text { Early } \\
\text { Miocene }\end{array}$ & $40, \mathrm{CC}$ & $\begin{array}{l}\text { Siliceous marly } \\
\text { nanno chalk }\end{array}$ & 50 & Calcite $>$ Quartz & $(\text { Opal-A })^{\mathrm{a}}$ \\
\hline $\begin{array}{l}\text { Middle } \\
\text { Oligocene }\end{array}$ & $44, \mathrm{CC}$ & $\begin{array}{l}\text { Siliceous marly } \\
\text { nanno chalk }\end{array}$ & 60 & Quartz (Calcite) ${ }^{a}$ & Opal-A \\
\hline $\begin{array}{l}\text { Early } \\
\text { Oligocene } \\
\text { Early }\end{array}$ & $45, \mathrm{CC}$ & Nanno chalk & 62 & Quartz>Calcite & $(\text { Opal-A })^{\mathrm{a}}$ \\
\hline Oligocene & $46, \mathrm{CC}$ & Nanno chalk & 70 & Quartz & - \\
\hline $\begin{array}{l}\text { Middle } \\
\text { Eocene }\end{array}$ & $47, \mathrm{CC}$ & Calcareous mudstone & 23 & Quartz. & $\begin{array}{c}\text { Clinoptilolite } \\
\text { Opal-A }\end{array}$ \\
\hline $\begin{array}{l}\text { Middle } \\
\text { Eocene }\end{array}$ & $49, \mathrm{CC}$ & Siliceous mudstone & 29 & Quartz. & $\begin{array}{l}\text { Clinoptilolite } \\
(\text { Opal-A })^{\mathrm{a}}\end{array}$ \\
\hline $\begin{array}{l}\text { Middle } \\
\text { Eocene }\end{array}$ & $51, \mathrm{CC}$ & $\begin{array}{l}\text { Marly calcareous } \\
\text { chalk }\end{array}$ & 32 & Quartz (Calcite) & $\begin{array}{c}\text { Clinoptilolite } \\
(\text { Opat-A })^{\mathrm{a}}\end{array}$ \\
\hline $\begin{array}{l}\text { Early } \\
\text { Eocene }\end{array}$ & $54, \mathrm{CC}$ & $\begin{array}{l}\text { Marly calcareous } \\
\text { chalk }\end{array}$ & 43 & Quartz $>$ Calcite & $\begin{array}{l}(\text { Opal-A })^{\mathrm{a}} \\
\text { Clinoptilolite }\end{array}$ \\
\hline $\begin{array}{l}\text { Late } \\
\text { Paleocene }\end{array}$ & $57, \mathrm{CC}$ & $\begin{array}{l}\text { Marly calcareous } \\
\text { chalk }\end{array}$ & 36 & - & $\begin{array}{l}\text { Clinoptilolite } \\
\text { Clinoptilolite }\end{array}$ \\
\hline Albian & $63, \mathrm{CC}$ & Marly nanno chalk & 54 & Calcite & $(\text { Opal-CT })^{\mathrm{a}}$ \\
\hline Albian & $64, \mathrm{CC}$ & Calcareous mudstone & 15 & (Quartz) $^{\mathrm{a}}$ & Clinoptilolite \\
\hline Albian & $65, \mathrm{CC}$ & Calcareous mudstone & 22 & (Calcite, Quartz) $^{\mathrm{a}}$ & Clinoptilolite \\
\hline Albian & $66, \mathrm{CC}$ & Calcareous mudstone & 19 & (Calcite, Quartz) $^{\mathrm{a}}$ & Clinoptilolite \\
\hline Aptian & $71, \mathrm{CC}$ & $\begin{array}{l}\text { Marly calcareous } \\
\text { chalk }\end{array}$ & 45 & Calcite & $\begin{array}{l}\text { Rhodochrosite } \\
\text { Clinoptilolite }\end{array}$ \\
\hline Aptian & $74, \mathrm{CC}$ & Mudstone & 6 & Calcite & Pyrite \\
\hline
\end{tabular}

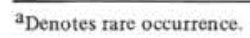

The mode of occurrence of the minerals is shown in Figure 4, where the bulk composition of $\mathrm{CaCO}_{3}$ is taken to represent cation concentration in the sediments. It is apparent in this figure that clinoptilolite occurs when carbonate is less than 60 per cent and opal-CT (plus quartz?) occurs when carbonate is over 80 per cent. According to Lancelot (1973), quartzose nodules are restricted to carbonate environments and opal-CT occurs in clayey sediments. Chemical analysis of opal-CT shows that they contain an appreciable amount of alkaline and alkaline earth elements (Millot, 1970), which means that if foreign cations
TABLE 4

X-Ray Powder Diffraction Data of Siliceous Organisms Picked up From Samples ( $>44 \mu \mathrm{m})$ in Hole 400A

\begin{tabular}{llcc}
\hline & & \multicolumn{2}{c}{ X-Ray Data } \\
\cline { 3 - 4 } \multicolumn{1}{c}{ Age } & Sample & Sponge Spicules & Radiolarians \\
\hline Early Miocene & 40, CC & Opal-A & \\
Early Oligocene & 45, CC & Opal-A & \\
Middle Eocene & 49, CC & & Clinoptilolite \\
Middle Eocene & $51, \mathrm{CC}$ & Opal-A (Clinoptilolite) & Clinoptilolite \\
Early Eocene & $54, \mathrm{CC}$ & Opal-A $>$ Clinoptilolite & Clinoptilolite \\
Albian & $63, \mathrm{CC}$ & & Opal-CT>Clinoptilolite \\
Albian & $64, \mathrm{CC}$ & & Clinoptilolite \\
Albian & $65, \mathrm{CC}$ & & Clinoptilolite \\
Albian & $66, \mathrm{CC}$ & & Clinoptilolite \\
\hline
\end{tabular}

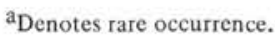

are available in appreciable amount, opal-CT can precipitate. The experimental results by Kastner et al. (1977) suggest that magnesium hydroxides are the most important components responsible for the increased rate of opal-A diagenesis. This is analogous to aragonite, an unstable form of calcite, which precipitates in the presence of magnesium ions (Health and Moberly, 1971). In carbonates of over 80 per cent $\mathrm{CaCO}_{3}$, as in Figure 4, both the scarcity of aluminum and metallic cations favor precipitation of opalCT only.

Observation of the cores in Site 406 indicated that the diatomites in Samples 38,CC and 39,CC were very fresh and composed entirely of opal-A (Table 2). Dissolution of the diatomites has not been extensive and no diagenetic changes seem to have occurred. Yet, observation strongly suggests that dissolution of the diatomites is the most probable source of silica and the dissolved silica concentration must have been above the equilibrium solubility of 


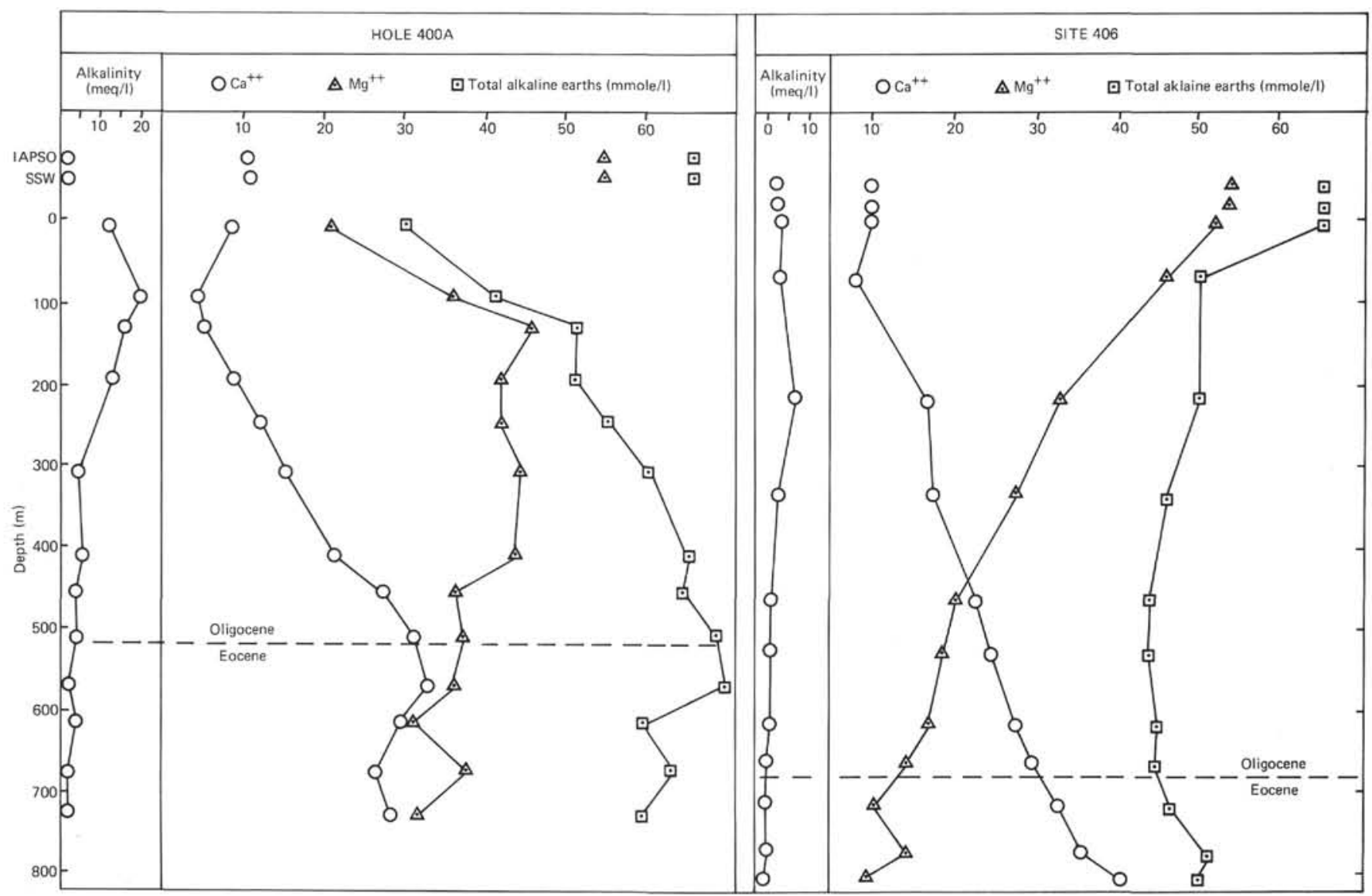

Figure 3. Change in concentration of interstitial alkaline-earth ions and alkalinity measurements in Hole 400A of the Bay of Biscay, and Site 406 of the Rockall Bank. Data are from Inorganic Geochemistory Section of this volume.

opal-CT and precipitated to form opal-CT at the surrounding places (e.g., Samples $37, \mathrm{CC}$ and $40, \mathrm{CC}$ ) where the carbonate contents are over 80 per cent. Obviously, as already noted by Heath and Moberly (1971), some circulation of silica-rich pore waters is required in the sediments over a range of several meters.

\section{ACKNOWLEDGMENTS}

The author gratefully acknowledges the aid and encouragement of the following people: Lucien Montadert, David G. Roberts, Robert W. Thompson, and Gerard A. Auffret. He also has benefited greatly from numerous discussions with Noriyuki Nasu and Masao Inoue. He is grateful to Steve E. Calvert and Minoru Utada for their critical comments on this paper. Financial support has been provided by the Government of Japan through the Ocean Research Institute, University of Tokyo, to assist Japanese IPOD activities.

\section{REFERENCES}

Calvert, S.E., 1971. Composition and origin of North Atlantic deep sea cherts, Contrib. Mineral. Petrol., v. 33, p. 273-288. , 1974. Deposition and diagenesis of silica in marine sediments, Spec. Publ. Int. Assoc. Sediment, v. 1, p. 273-299.

Ernst, W.G. and Calvert, S.E., 1969. An experimental study of the recrystallization of porcelanite and its bearing on the origin of some bedded cherts, Am. J. Sci., v. 267-A, p. 114-133.

Heath, G.R. and Moberly, R., 1971. Chert from the western Pacific, Leg 7, Deep Sea Drilling Project. In Winterer, E.L., et al., Initial Reports of the Deep Sea Drilling Project, v. 7, Pt. 2; Washington (U.S. Government Printing Office), p. 991-1008.

Imoto, N. and Fukutomi, M., 1975. Genesis of bedded cherts in the Tamba Belt, southwest Japan, Assoc. Geol. Collabor. Japan, Monogr., v. 19, p. 35-42.

Inoue, M., 1973. Crystallization and recrystallization of siliceous sponge spicules in some marine sediments of Japan, J. Geol. Soc. Japan, v. 79, p. 277-286.

Jones, J.B. and Segnit, E.R., 1971. The nature of opal, 1. Nomenclature and constituent phases, J. Geol. Soc. Australia, v. 18 , p. $57-68$.

Kastner, M., Keene, J.B., and Gieskes, J.M., 1977. Diagenesis of siliceous oozes-1. Chemical controls on the rate of opal-CT transformation - an experimental study, Geochim. Cosmochim. Acta, v. 41, p. 1041-1059.

Lancelot, Y., 1973. Cherts and silica diagenesis in sediments from the central Pacific. In Winterer, E.L., Ewing, J.I., et al., Initial Reports of the Deep Sea Drilling Project, v. 17: Washington (U.S. Government Printing Office), p. 377-405.

MacKenzie, F.T. and Garrels, R.M., 1966. Chemical mass balance between rivers and oceans, Am. J. Sci., v. 264, p. $507-$ 525 .

Manheim, F.T. and Sayles, F.L., 1974. Composition and origin of interstitial waters of marine sediments, based on deep sea drill cores, The Sea, v. 5, p. 527-568.

Mariner, R.H. and Surdam, R.C., 1970. Alkalinity and formation of zeolites in saline alkaline lakes, Science, v. 70, p. 977-980.

McBride, E.F. and Thomson, A., 1970. The Caballos Novaculite, Marathon region, Texas, Geol. Soc. Am., Spec. Paper, 122. 


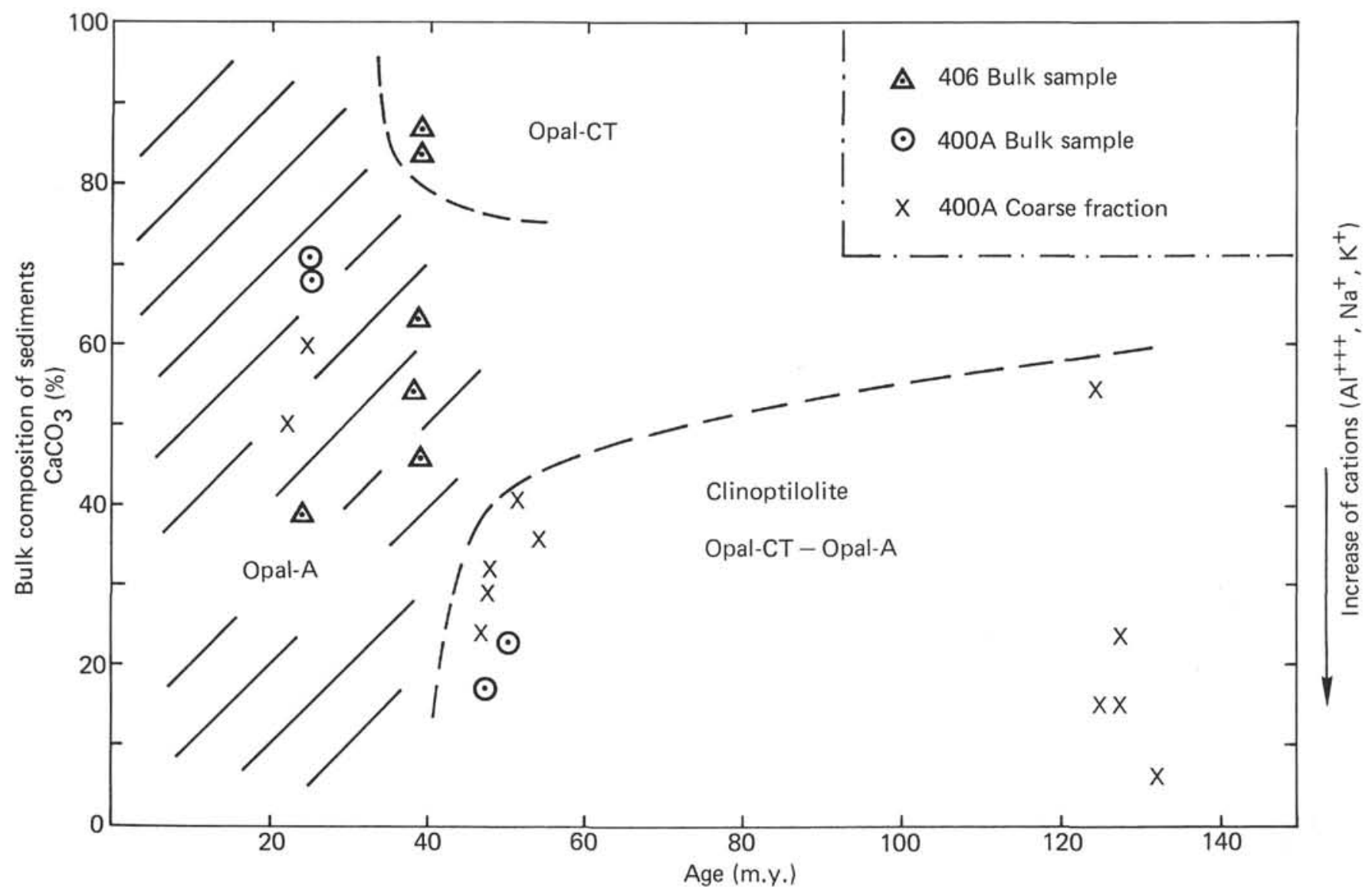

Figure 4. Mode of occurrence of silica minerals in Hole 400A of the Bay of Biscay and Site 406 of the Rockall Bank.

Millot, G., 1970. Geology of Clay: New York (Springer-Verlag). Stein, C.L. and Kirkpatrick, R.J., 1976. Experimental porcelanate recrystallization kinetics: A nucleation and growth model, $J$. Sediment. Petrol., v. 46, p. 430-435.

Surdam, R.C. and Parker, R.D., 1972. Authigenic aluminosilicate minerals in the tuffaceous rocks of the Green River Formation, Wyoming, Geol. Soc. Am. Bull., v. 83, p. 689-700. von Rad, U. and Rösch, H., 1974. Petrography and diagenesis of deep-sea cherts from the central Atlantic, Spec. Publ. Int. Assoc. Sediment, v. 1, p. 327-347.

Weaver, F.M. and Wise, S.W., Jr., 1972. Ultra morphology of deep sea cristobalitic chert, Nature, Phys. Sci., v. 237, p. 56-57. 